Al-Bidayah : jurnal pendidikan dasar Islam

Volume 12, Number 1, June 2020

ISSN: 2549-3388 (online)

Available online at https://jurnal.albidayah.id

Submitted: September 7, 2019, Accepted: May 20, 2020

\title{
THE IMPLEMENTATION OF HIGHER-ORDER THINKING SKILLS (HOTS) IN TEXT-BASED LEARNING AT SDN BANYURIP 3 SAMBUNGMACAN
}

\author{
Tiya Agustina ${ }^{1}$, Wahyu Oktavia ${ }^{2}$, Elen Inderasari ${ }^{3}$

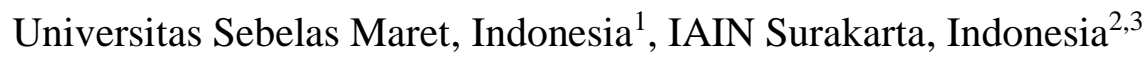 \\ Email: tiyaagustina@student.uns.ac.id ${ }^{1}$, oktaviawahyu17@gmail.com², \\ inderasari85iain@gmail.com ${ }^{3}$
}

DOI: $\underline{10.14421 / \text { al-bidayah.v12i1.253 }}$

\begin{abstract}
Current learning must be directed at higher-order thinking skills and text-based. This condition certainly requires an adaptation process that is not easy. Based on these problems, this study aims to describe the implementation of Higher Order Thinking Skills (HOTS) in text-based learning at State Elementary School of Banyurip 3 Sambungmacan or called SDN Banyurip 3 Sambungmacan. This research is descriptive qualitative research. Data collection techniques used in this study, namely observation, interviews, and documentation. The documents used in this study are in the form of a syllabus, lesson plans, and photos of the learning process. Data validity is done using the triangulation of sources and methods. The data analysis techniques used include data collection, data reduction, data presentation, and concluding. The formulation of the problems examined in this study shows how (1) HOTS planning in text-based learning (2) HOTS implementation in text-based learning (3) HOTS assessment in text-based learning (4) how the constraints experienced in the application of HOTS in text-based learning. The results showed that the planning and implementation of text-based learning had gone well. The selection of learning components has been able to build a HOTS learning atmosphere. Text-based learning assessments in elementary schools have used authentic assessments. Obstacles experienced by teachers in the process of text-based learning include; arrange the right plan, the difficulty in dividing the time allocation, the selection of the right media, the suitability of learning resources with student characteristics, the integration of interesting learning methods.
\end{abstract}

\section{Keywords: 2013 curriculum; HOTS; text learning; elementary school}

\section{INTRODUCTION}

Since the implementation of curriculum 2013, every learning is more directed to use scientific or scientific approaches. Learning with this approach is used to prioritize student activity, where students are required to be independent in finding material related to specific subjects. ${ }^{1}$ Thus students are directed to find and transform complex information, examine new information with those already in their memories, and obtain knowledge based on scientific methods independently. The scientific approach in the 2013 curriculum includes various stages of observing (to identify or find problems), formulating questions, proposing or formulating hypotheses, collecting data with multiple

${ }^{1}$ Mahsun, Teks Dalam Pembelajaran Bahasa Indonesia: Kurikulum 2013 (Jakarta: RajaGrafindo Persada Press, 2014). 
techniques, analyzing data, drawing conclusions, and communicating concepts. ${ }^{2}$ The process is expected to train students to think analytically, not mechanically. ${ }^{3}$

In the process of its implementation, the 2013 curriculum continues to experience changes by educational objectives to develop the potential of students as a whole. These changes are contained in the Minister of Education and Culture (MoEC) Regulation No. 22 of 2016 which explains that the learning process must integrate literacy, 4C, and Higher Order Thinking Skills (HOTS) as challenges for the 21 st-century learning. ${ }^{4}$ The application of HOTS to content standards is designed so that students can think critically and analytically by international standards by reducing irrelevant material and deepening and expanding the material relevant to students. Whereas the assessment standard is done by adopting global standard assessment models gradually. Assessment of learning outcomes focuses more on higher-order thinking skills (HOTS). ${ }^{5}$

Higher-order thinking skills are defined as the wider use of the mind to find new challenges. ${ }^{6}$ The process is carried out by someone by recalling the knowledge that has been stored in his memory for a time used in receiving information, processing, and inferring something. ${ }^{7}$ High-level thinking is thinking at a higher level than just memorizing facts or saying something to someone exactly like how things are it was delivered. ${ }^{8}$ As a process of thinking at a higher cognitive level, this skill is developed

2 Umi Pratiwi and Eka Farida Fasha, "Pengembangan Instrumen Penilaian HOTS Berbasis Kurikulum 2013 Terhadap Sikap Disiplin," Jurnal Penelitian dan Pembelajaran IPA 1, no. 1 (November 12, 2015): 123-42, https://doi.org/10.30870/jppi.v1i1.330.

3 Abdul Majid and Chaerul Rochman, Pendekatan Ilmiah Dalam Implementasi Kurikulum 2013 (Bandung: Remaja Rosdakarya, 2014).

${ }^{4}$ Yoki Ariyana et al., Buku Pegangan Pembelajaran Berorientasi Keterampilan Berpikir Tingkat Tinggi (Jakarta: Direktorat Jenderal Guru dan Tenaga Kependidikan, Kementerian Pendidikan dan Kebudayaan Republik Indonesia, 2018).

${ }^{5}$ MOEC, Modul Penyusunan Higher Order Thinking Skill (HOTS) (Jakarta, Indonesia: Ministry of Education and Culture (MOEC), 2017).

${ }^{6}$ Yee Mei Heong et al., "The Level of Marzano Higher Order Thinking Skillsamong Technical Education Students," International Journal of Social Science and Humanity, 2011, 121-25, https://doi.org/10.7763/IJSSH.2011.V1.20.

${ }^{7}$ Chintia Tri Noprinda and Sofyan M. Soleh, "Pengembangan Lembar Kerja Peserta Didik (LKPD) Berbasis Higher Order Thinking Skill (HOTS)," Indonesian Journal of Science and Mathematics Education 2, no. 2 (July 31, 2019): 168-76, https://doi.org/10.24042/ijsme.v2i2.4342.

${ }^{8}$ Nur Astuti Puspaningtyas, "Peningkatan Higher Order Thinking Skills (HOTS) Melalui Strategi Pembelajaran Peningkatan Kemampuan Berpikir (SPPKB) Pada Pembelajaran Ekonomi Kelas X SMK Muhammadiyah 1 Wates" (Yogyakarta, Universitas Negeri Yogyakarta, 2018), https://eprints.uny.ac.id/59666/1/Skripsi_Nur\%20Astuti\%20Puspaningtyas_14804244003.pdf. 
from various concepts and learning methods such as problem-solving, teaching taxonomy, and assessment. ${ }^{9}$

The teaching taxonomy and assessment form the basis for developing higherorder thinking skills in Bloom's taxonomy which was revised by Anderson and Krathwohl. In Bloom's taxonomy, the three cognitive domains that are part of higherorder thinking skills are analyzing (C4), evaluating (C5), and creating (C6). The cognitive aspects will produce critical thinking skills, creative, problem solving, and making decisions. ${ }^{10}$ Under educational policies, these skills must be applied in learning.

In applying the policy, the teacher must be able to bring up the students' highlevel thinking skills. One way to train students to think at a higher level, among others, is by creating learning that develops the ability of students to analyze, evaluate, and design with the use of appropriate teaching material books. ${ }^{11}$ HOTS requires learners to utilize information and ideas by changing their meanings and implications. This demand is like when a learner combines facts and ideas, then synthesizes, generalizes, explains, hypotheses, or concludes. ${ }^{12}$

The optimizing of the ability to think at a higher level, the 2013 curriculum demands that learning materials be optimally designed, so that students can predict, design, and predict. ${ }^{13}$ This text-based learning is used as a way to improve the thinking skills of Indonesian subjects in the realm of knowledge and skills. ${ }^{14}$ Based on the study of basic competencies in the 2013 curriculum for elementary schools (ES) or madrasah ibtidaiyah (MI) Indonesian subjects found 28 texts, which included seven literary texts (25\%) and 21 non-literary texts (75\%). The substance of the text in the 2013 curriculum

${ }^{9}$ Husna Nur Dinni, "HOTS (High Order Thinking Skills) Dan Kaitannya Dengan Kemampuan Literasi Matematika," in Prosiding Seminar Nasional Matematika (Semarang, 2018), 170-76., https://journal.unnes.ac.id/sju/index.php/prisma/article/view/19597.

10 Ridwan Abdulllah Sani, Pembelajaran Berbasis HOTS (Higher Order Thinking Skills) (Tangerang: Tira Smart, 2019).

${ }^{11}$ Winarno Winarno, Widha Sunarno, and Sarwanto Sarwanto, "Pengembangan Modul IPA Terpadu Berbasis High Order Thinking Skill (HOTS) Pada Tema Energi," INKUIRI: Jurnal Pendidikan IPA 4, no. 1 (2015): 82-91, https://doi.org/10.20961/inkuiri.v4i1.9562.

12 Indrya Mulyaningsih and Itaristanti Itaristanti, "Pembelajaran Bermuatan HOTS (Higher Order Thinking Skill) Di Jurusan Tadris Bahasa Indonesia," Indonesian Language Education and Literature 4, no. 1 (December 25, 2018): 113-28, https://doi.org/10.24235/ileal.v4i1.2970.

13 Pipit Pudji Astutik, "Integrasi Penguatan Pendidikan Karakter (IPK) Dan Higher Order Thinking Skills (HOTS) Dalam Pembelajaran Tematik SD," in Seminar Nasional Pendidikan (Malang: Universitas Negeri Malang, 2017), 343-54, http://ap.fip.um.ac.id/wp-content/uploads/2017/12/Pipit-Pudji-Astutik.pdf.

${ }^{14}$ Endah Tri Priyatni, Desain Pembelajaran Bahasa Indonesia Dalam Kurikulum 2013 (Jakarta: Bumi Aksara, 2017). 
at the ES/MI level is language learning and literature used to teach science and social science material. ${ }^{15}$ In this regard, several reasons regarding the use of text in 2013 curriculum learning, namely through the text students' thinking ability can be developed. Besides, the selection of material in the form of text is more relevant to the characteristics of the 2013 curriculum, which sets the achievement of competencies in knowledge, skills, and attitudes. ${ }^{16}$

One of the elementary schools that have implemented HOTS in text-based learning are a public elementary school Banyurip 3 Sambungmacan, Sragen. Based on the results of observations and preliminary interviews conducted on class teachers, viceprincipal of curriculum, and the headmaster of SDN Banyurip 3 Sambungmacan, the school has implemented HOTS in text-based learning. Every class teacher has been given training, both through MGMP, workshops, and seminars. The statement is also evident from initial observations. The teacher's 4th-grade has applied HOTS in the planning, implementation, and evaluation or assessment stages. Not only that, but the teacher is also able to arouse the motivation and activeness of students in the learning process. Critical thinking skills, creative, problem solving, and decision making have been applied by the teacher. Although conceptually the teacher has been able to apply, sometimes some obstacles result in learning not being implemented optimally.

Related to this background, this study aims to describe the application of HOTS in learning at SDN 3 Banyurip Sambungmacan. In this case, the assessment is carried out on aspects of documents and processes that are directly related to classroom learning. Documents and learning processes are used to interpret the results of the application of HOTS at SDN Banyurip 3 Sambungmacan, starting from planning, implementation, and evaluation or assessment. Also, this study wants to look at some of the obstacles experienced by teachers during the HOTS learning process.

This study has relevance to previous research, namely Nurdinah Hanifah's research (2019) entitled "Development of Higher Order Thinking Skill Assessment

15 Main Sufanti, "Pembelajaran Bahasa Indonesia Berbasis Teks: Belajar Dari Ohio Amerika Serikat," in Seminar Nasional: Teks Sebagai Media Pembelajaran Bahasa Indonesia Dalam Menyonsong Kurikulum (Surakarta: Universitas Muhammadiyah Surakarta, 2013), 36-65, https://publikasiilmiah.ums.ac.id/bitstream/handle/11617/3363/2_Pembelajaran\%20Bahasa\%20Indonesia $\%$ 20Berbasis\%20Teks\%20Belajar\%20Dari\%20Ohio\%20Amerika\%20Serikat.pdf?sequence=1.

${ }^{16}$ Mahsun, Teks Dalam Pembelajaran Bahasa Indonesia: Kurikulum 2013. 
Instruments (HOTS) in Primary Schools". ${ }^{17}$ Furthermore, Usmaedi's research (2017) with the title "Initiating HOTS Learning in Primary School Age Children" discusses the importance of optimizing thinking skills in primary school level learning. ${ }^{18}$ The difference between previous research lies in research studies. If Hanifah's research only emphasizes aspects of HOTS assessment, this research focuses more on the learning process, namely planning, implementation, and evaluation or assessment. Meanwhile, if Usmaedi's research discusses the HOTS concept, then this research emphasizes the HOTS learning practices that have been applied by the teacher. However, the two studies have similarities in the object of research, namely researching learning at the elementary school level.

Given this view, this study seeks to provide an overview of the application of HOTS in text-based learning at the elementary school level. Besides, it also examines the obstacles experienced by teachers in implementing HOTS. It is hoped that this research can be used as a reference source for teachers in implementing HOTS learning.

\section{RESEARCH METHODS}

Based on the background that has been described, this research is a qualitative descriptive study. The researchers' reason applied the qualitative descriptive research is this research studied the phenomena about what is experienced by research subjects, such as behavior, perception, motivation, actions, etc. holistically and using descriptions in the form of words and language, in a specific context that is natural.. ${ }^{19}$

This research was carried out at SDN Banyurip 3 Sambungmacan. Data sources used in this study were learning events, informants used included class teachers, curriculum heads and school principals, and documents in the form of syllabi, lesson plans, teaching materials. The data was collected through several techniques, namely observation, interview, questionnaire, documentation, and a combination of the four. The data validity test in this research was conducted using source and method triangulation.

\footnotetext{
${ }^{17}$ Nurdinah Hanifah, "Pengembangan Instrumen Penilaian Higher Order Thinking Skill (HOTS) Di Sekolah Dasar," Current Research in Education: Conference Series Journal 1, no. 1 (January 1, 2019): 005, https://ejournal.upi.edu/index.php/crecs/article/view/14286.

${ }^{18}$ Usmaedi Usmaedi, "Menggagas Pembelajaran HOTS Pada Anak Usia Sekolah Dasar," Jurnal Pendidikan Sekolah Dasar 3, no. 1 (2017): 82., https://jurnal.untirta.ac.id/index.php/jpsd/article/view/1040.

${ }^{19}$ Lexy J. Moleong, Metodologi Penelitian Kualitatif (Bandung: Remaja Rosdakarya, 2017).
} 
Then in the analysis phase is done by data collection, data reduction, presentation, and concluding.

\section{RESULT AND DISCUSSION}

The application of HOTS in text-based learning on students at SDN Banyurip 3 Sambungmacan consisted of three steps were planning, implementation, and assessment. The explanation of the three-steps of HOTS in the text-based learning process, namely the following.

\section{Planning Text-Based HOST Learning}

The teaching plan is the initial stage in the learning process. As a facilitator, the teacher must draw up a detailed learning plan by paying attention to various components to fit the expected goals. The planning will be a reference for teachers in carrying out the teaching and learning process in the classroom. Besides, learning planning will also determine the course of learning that students will go through. As for what is included in the learning plan are the syllabus and lesson plan (LP).

In the revised 2013 curriculum, the preparation of the syllabus was transferred to the authority of the central government, except for certain subjects developed explicitly in the relevant education unit. Thus, teacher authority only develops lesson plans based on syllabi prepared by the government, teacher manuals, and student manuals. The syllabus is a reference framework for the preparation of learning for each learning material. The syllabus is developed from Graduates' Competency Standards and Content Standards by learning patterns in a particular school year. Therefore, the teacher must understand the purpose of the syllabus, especially in the operational part of learning.

The preparation of the LP has become the authority of each subject teacher. Based on the results of the study, text-based learning lesson plans at the elementary school level were prepared by the teacher by referring to the teacher, student, and syllabus books. The teacher prepares lesson plans based on the results of the subject teacher meeting (Musyawarah Guru Mata Pelajaran) in all Sragen regencies. Then, the teacher develops the lesson plans that the subject teacher meeting (STM) has prepared according to the needs of elementary school students. Based on the results of the study, the teacher makes the HOTS's LP by paying attention to the following steps. 
The first step is to study of the syllabus content. At this stage, the teacher examines the syllabus by paying attention to several aspects, including core competencies, basic competencies, learning materials, learning processes, learning assessment, time allocation, and learning resources. Core Competencies or called Kompetensi Inti (KI) include: (1) the spiritual attitude's KI (KI-1); (2) the social attitude's KI (KI-2): (3) knowledge's KI (KI-3), and (4) skills' KI (KI-4) that function as the integration of learning content, subjects, or program in achieving graduate competence standard or called Standard Kompetensi Lulusan (SKL).

The second step is to determine the type of skills under basic competencies. At this stage, the teacher identifies basic competencies or called Kompetensi Dasar (KD) that demand higher-order thinking skills or HOTS. The step taken by the teacher is to look at the verbs found in the basic competency. Basic competencies that use operational verbs $(\mathrm{OV})$ analyze $(\mathrm{C} 4)$, evaluate $(\mathrm{C} 5)$, and create (C6) are basic competencies that demand higher-order thinking skills. The basic competency must be developed by the teacher in the form of HOTS learning.

The third step is to formulate the learning objectives. Learning objectives are aspects that need attention in planning learning because every activity always refers to the achievement of learning objectives. Learning objectives consist of the audience (A), behavior (B), condition (C), and degree (D). The audience is a subject as well as an object in learning, namely students. Behavior is the behavior or activity that students can show after participating in learning. Behavior consists of only one learning activity expressed in the form of operational verbs (OV). This formulation confirms that students must not do more than one deed, so they can obtain optimal learning outcomes. Condition is the state of students before and after learning activities. The degree is the level of mastery or performance that can be done by students after going through a series of learning processes. The determinant of degree-level was learning material and the extent to which students must master a material. ${ }^{20}$ The degree is the level of mastery or performance that can be done by students after going through a series of learning processes. The teacher formulated the learning objectives in the lesson plan that contained audience, behavior, and condition components. However, the degree component is not yet included in the

${ }^{20}$ Istiqomah, Pembelajaran Dan Penilaian Higher Oerder Thinking Skills: Teori Dan Inspirasi Pembelajaran Untuk Menyongsong Era Revolusi Industri 4.0 (Surabaya: Pustaka MediaGuru, 2018). 
goals set by the teacher. The teacher also explained that HOTS learning objectives were developed by incorporating learning approaches and models, the 21 st-century skills developed, and the values of character education.

The fourth step is the formulation of competency achievement indicators (CAI). Indicators of competency achievement are the results of the translation of basic competencies that can be measured or observed to show the achievement of basic competencies. Based on the results of the study, it can be said that the lesson plans prepared by the teacher to meet three criteria, which contain clear sentences, have definite meanings, and can be measured. The clarity of statements means students and teachers have the same understanding of the meaning of the sentence. Certainty means it does not cause a double meaning. Besides, indicators can also be measured in the form of behavioral attainment. In general, when viewed from the KKO in the KD to be studied, there are three types of CAI, namely key indicators, bridge or support indicators, and enrichment indicators. In developing HOTS indicators, the teacher always pays attention to the taxonomy of thinking. As for what the teacher is referring to is Bloom's taxonomic level, especially at the C4, C5, and C6 levels.

The fifth step is the development of learning materials. One of the components that determines the achievement of basic competencies is learning material. Learning material is the subject of discussion that contains messages in the form of facts, concepts, principles, and procedures. In this regard, learning material must be arranged according to indicators of competency achievement. It is emphasized that the teacher must be able to develop or create multimedia text material. That means the material presented in the form of varied texts such as print, audio, visual, or audiovisual. Also, the teacher must be able to teach material from various sources and not only come from textbooks.

Based on the results of the study, the material presented in the LP has included facts, concepts, principles, and procedures under the indicators to be achieved. In this context, the material planned by the teacher is the description text material. The teacher develops the material by taking several readings contained in books, nature, newspapers, magazines, and the internet. The material presented by the teacher also supports the occurrence of literacy activities, namely by reading or listening to the text given by the teacher before starting the learning material. Therefore, the selection of appropriate learning resources will affect the level of student interest in learning. 
The sixth step is the development of HOTS learning stages. The implementation of learning requires planning the steps of activities so that learning cannot be separated from the competencies to be achieved. The steps include preliminary, core, and closing activities. The three activities that have been described must be carried out systematically and sequentially because the three are interrelated. Based on the results of the study, the RPP prepared by the fourth-grade teachers of SDN Banyurip 3 Sambungmacan already contained details of the preliminary, core, and closing activities. Each activity has been described in detail by the teacher. However, the teacher does not only emphasize the core activities, introduction and closing are also interestingly arranged by the teacher so that students have a good impression of the learning material. The method used by the teacher is also very varied, namely discussion, independent assignment, and group assignments. Besides, the teacher also uses the problem-based learning model to train students to think critically. The project-based learning model is used by the teacher to help students produce both individual and group work. Besides, the teacher also revealed that the learning model used is often varied with other models so that it can create innovations in developing HOTS-based learning.

The seventh step is to determine the instructional media. The selection of the right media will affect students' interest in learning. The instructional media have chosen by teachers in the XXI century, and the era of the industrial revolution must be able to encourage the HOTS learning process. The teacher must be able to choose, use, or create multimedia learning media in print, audio, audiovisual based on information technology. Based on this research, RPP compiled the teacher has attached the text learning media in the form of examples, while the tools used are laptops and LCD. ${ }^{21}$ However, in reality, on the ground the teacher does not use these tools, so learning is more focused on the use of objects that are in the surrounding environment. Also, the suitability of instructional media with student characteristics is not optimal because the media in the form of text samples are considered less attractive.

The eight-step is to determine the time allocation. In HOTS-based learning, teachers must be able to divide their time into three activities, namely introduction, core, and closing. Under the 2013 curriculum rules, teachers can adjust the time allocation of each KD according to the situation and condition of the school. Also, teachers must be

\footnotetext{
${ }^{21}$ Istiqomah.
} 
able to allocate independent assignments outside of learning hours. Based on the results of the study, teachers have difficulty in allocating time. The time allocation stated in the LP was sometimes not following its implementation. This condition makes the material delivered by the teacher can not be completed at the meeting. As the result, the teacher must provide additional tasks that can be done outside of learning hours.

The ninth step is development the a learning assessment. The next component that must be formulated by the teacher is the form and type of assessment. Assessment in the 2013 curriculum is known as authentic assessment. The scope of the assessment includes attitudes, knowledge, and skills. Technical development and assessment must be adjusted to the learning objectives and IPK. Teachers are expected to be able to consider the content of questions related to PPK, XXI century skills, and HOTS. Based on the results of the study, the assessment attached to the teacher in the lesson plan includes two forms, namely process assessment and outcome assessment. The instrument used to assess the results of text-based learning in the form of portfolio assessment. Also, the forms, techniques, and instruments listed by the teacher have been completed with indicators and assessment of writing skills.

\section{Implementation of Text-Based HOTS Learning}

The implementation of learning is the second stage of the learning process. Besides, this step is the application of the learning plan that has been done before. The intended planning is the LP. In connection with this, the lesson plan is a description of the activities that will be carried out in learning. Therefore, the LP serves as the primary reference in the implementation of learning. At the implementation stage of the teacher, learning has three main roles, namely as a planner, facilitator, and evaluator. As a facilitator, the teacher implements assignments together. This implementation was done in groups through a discussion. The teacher's task is to guide and direct students according to the context of the material. As evaluators, the teacher has the responsibility to help and guide students who have difficulty understanding the material. The implementation of text-based learning at the elementary school level is influenced by several components that build the implementation of the learning. Based on the results of the study, teachers carry out learning with a time allocation of $2 \times 35$ minutes.

In the learning process, the activities carried out by the teacher can form higherorder thinking skills. HOTS produced several skills, namely critical thinking, creative, 
problem solving, and making decisions. Critical thinking activities are seen when students are presenting their group assignments. In these activities, each group member is very active in giving responses and suggestions to the work of other groups. The group that is presenting the results does not want to be dropped; they defend their opinions with strong arguments. The teacher in this stage acts as an intermediary, which is only tasked with reinforcing the work of students. As explained, critical thinking skills are carried out using thought processes to analyze arguments and provide correct interpretations. ${ }^{22}$

Problem-solving skills, proven when the moderator or group leader can capture all the opinions expressed by each group. The opinion is concluded based on the correct answer. This process trains students to become accustomed to using the power of thinking rationally in solving problems. Likewise on the contrary, at the stage of making decisions students must be able to determine the correct answer from each argument submitted by each group. They must be able to use their thought processes to choose the best decision from several choices.

As for the creative thinking process, it can be proven by showing that students when they are required to develop actual problems in the form of texts. At this stage the teacher guides students to search for and find some problems that can be used as topics in developing texts. By giving these assignments students are very active in asking questions and discussing with the teacher the accuracy of the selection of problems to be developed in the form of text. The process can train students to generate new ideas based on concepts or perceptions that each individual has. Therefore, it can be said that higherorder thinking skills have a relationship with one another. It is also emphasized that these skills are interrelated, and it is difficult to distinguish them because these skills are integrated. ${ }^{23}$

\section{Text-Based HOTS Learning Assessment}

Learning evaluation is the process of determining the value of learning carried out through learning assessment or measurement activities. Evaluation of learning outcomes is intended to determine the extent to which students can display performance as expected. Based on the results of the study, evaluations conducted by teachers were done in two forms namely process and outcome assessments. The assessment process is carried

\footnotetext{
${ }^{22}$ Martinis Yamin, Paradigma Baru Pembelajaran (Jakarta: Referensi, 2013).

23 Yamin.
} 
out by the teacher when the discussion process takes place. As for the assessment of results, teachers do regarding the work that has been compiled, students.

Product assessment is carried out to see the ability of students to produce certain works. This assessment was done in stages, starting from the stage of planning an idea to make a product, the stage of implementation, and assessment of results as the final stage in seeing the work of students who have finished producing. Thus, product evaluation not only evaluates the final result but also assesses the process of writing texts at each stage. The aspects assessed in the results of the text product include content, text structure, vocabulary, sentences, and mechanics.

MoEC's Regulation no. 23 of 2016 explains that portfolio assessment was evaluating the work of individual students in one period for a subject. During the assessment phase, the Indonesian teacher at ES/MI did an assessment based on the lesson plan (LP). The preparation of the instruments in the valuation has been completed with the assessment guidelines. The teacher uses portfolio techniques to assess the product of text produced by students under indicators of competency achievement. The guideline for assessing skills in composing text has been completed with aspects assessed, scores, and assessment criteria.

The importance of assessment in the learning process activities is something that needs serious attention, considering that assessment is an integral part that is inseparable from the learning process. Assessment is one of the activities carried out by teachers and students from a series of learning activities carried out. The teachers, as managers of learning in sued able to prepare and conduct assessments with the correct procedures so that the specified learning objectives are achieved. ${ }^{24}$

Based on the results of the review, it can be concluded that the assessment must be carried out under the specified indicators and instruments. Assessment as the final stage in learning as an evaluation material to measure the extent to which students can receive and understand lessons by predetermined indicators. Also, the teacher can determine the follow-up to the learning that has been carried out.

\footnotetext{
${ }^{24}$ Hamdani, Strategi Belajar Mengajar (Bandung: Pustaka Setia, 2011).
} 


\section{Constraints in Text-Based Learning Implementation HOTS}

The implementation of text-based learning at State Elementary School (ESS) of Banyurip 3 Sambungmacan has been going well. However, there are still some obstacles that arise and affect the success of the learning process. Constraints that arise in the process of text-based learning not only from the teacher but also from students, considering the teacher and students, are two components that interact with each other. In this regard, obstacles faced by teachers in implementing text-based learning include planning, teaching materials, methods, media, and time. This finding confirms the finding of Seman, et al., research that teachers, teaching and learning preparations and processes, and in the aspects of pupils are several aspects that become a challenge in implementing the HOTS teaching process in primary schools ${ }^{25}$

The obstacle experienced by the teacher at the stage of preparing the learning implementation plan is the systematic differences in the LP based on the revised 2013 curriculum. Teachers should draw up lesson plans so that learning is planned to run smoothly because of the LP is a benchmark in determining the success or failure of the implementation of learning. Systematics and the preparation of the LP format that has undergone such changes make teachers must readjust the LP have been prepared at the beginning of the school year. The teacher also has difficulty in dividing the time allocation in each activity, choosing engaging media, sources, and learning methods so that HOTS learning can be carried out maximally. The obstacles that arise in text-based learning do not only happen to the teacher. However, these obstacles are also experienced by students. Here are some of the obstacles students experience in text-based learning, namely concentration of learning, interest in learning, and difficulty developing text.

\section{CONCLUSION}

Based on the findings and discussion of the implementation of HOTS in textbased learning for students at SDN Banyurip 3 Sambungmacan obtained conclusions, among others, text-based learning planning conducted by the teacher is under the 2013 curriculum. First, planning is the initial stage in the learning process. At this stage, the

${ }^{25}$ Shamilati Che Seman, Wan Mazwati Wan Yusoff, and Rahimah Embong, "Teachers Challenges in Teaching and Learning for Higher Order Thinking Skills (HOTS) in Primary School," International Journal of Asian Social Science 7, no. $7 \quad$ (2017): 534-45., https://econpapers.repec.org/article/asiijoass/2017_3ap_3a534-545.htm. 
teacher makes a plan by studying the syllabus and preparing a lesson plan (LP) or in Indonesia, it is called Rencana Pelaksanaan Pembelajaran (RPP). The syllabus applied as a reference has been prepared by the central government, to make it easier for teachers to develop lesson plans. Based on the results of the study, it can be concluded that the LP prepared by elementary school teachers is by the revised edition systematic curriculum 2013.

Second, the implementation of text-based learning has gone well. The learning steps taken by the teacher have reflected aspects of HOTS which include critical thinking skills, creativity, problem-solving, and making decisions. The success of the process is supported by the selection of appropriate methods, models, and materials. The selection of learning components can build a HOTS learning atmosphere. This can be proven when students actively submit their arguments in the discussion forum. However, some components are not appropriate, such as the choice of instructional media and time allocation that is different from planning.

Third, the description of text-based learning assessments in elementary schools has used authentic assessments. Forms of the assessment conducted in learning in the form of an assessment of the process and results. The assessment process is related to the attitudes that students build during the learning process. The assessment process relates to the product results or student work from text-based learning.

Fourth, the obstacles experienced by teachers in the process of text-based learning include (1) preparing appropriate planning (2) difficulties in dividing the time allocation, (3) choosing the right media, (4) appropriateness of learning resources with student characteristics, (5) integrating interesting learning method. While the obstacles experienced by students include (1) concentration of learning, (2) interest in learning, and (3) difficulty in developing texts.

\section{REFERENCES}

Ariyana, Yoki, Ari Pudjiastuti, Reisky Bestary, and Zamroni. Buku Pegangan Pembelajaran Berorientasi Keterampilan Berpikir Tingkat Tinggi. Jakarta: Direktorat Jenderal Guru dan Tenaga Kependidikan, Kementerian Pendidikan dan Kebudayaan Republik Indonesia, 2018.

Astutik, Pipit Pudji. "Integrasi Penguatan Pendidikan Karakter (IPK) Dan Higher Order Thinking Skills (HOTS) Dalam Pembelajaran Tematik SD.” In Seminar Nasional 
Pendidikan, 343-54. Malang: Universitas Negeri Malang, 2017. http://ap.fip.um.ac.id/wp-content/uploads/2017/12/Pipit-Pudji-Astutik.pdf.

Dinni, Husna Nur. "HOTS (High Order Thinking Skills) Dan Kaitannya Dengan Kemampuan Literasi Matematika." In Prosiding Seminar Nasional Matematika, 170-76. Semarang, 2018 , https://journal.unnes.ac.id/sju/index.php/prisma/article/view/19597.

Hamdani. Strategi Belajar Mengajar. Bandung: Pustaka Setia, 2011.

Hanifah, Nurdinah. "Pengembangan Instrumen Penilaian Higher Order Thinking Skill (HOTS) Di Sekolah Dasar." Current Research in Education: Conference Series Journal 1, no. 1 (January 1, 2019): 005, https://ejournal.upi.edu/index.php/crecs/article/view/14286.

Heong, Yee Mei, Widad Binti Othman, Jailani Bin Md Yunos, Tee Tze Kiong, Razali Bin Hassan, and Mimi Mohaffyza Binti Mohamad. "The Level of Marzano Higher Order Thinking Skillsamong Technical Education Students." International Journal of Social Science and Humanity, 2011, 121-25. https://doi.org/10.7763/IJSSH.2011.V1.20.

Istiqomah. Pembelajaran Dan Penilaian Higher Oerder Thinking Skills: Teori Dan Inspirasi Pembelajaran Untuk Menyongsong Era Revolusi Industri 4.0. Surabaya: Pustaka MediaGuru, 2018.

Mahsun. Teks Dalam Pembelajaran Bahasa Indonesia: Kurikulum 2013. Jakarta: RajaGrafindo Persada Press, 2014.

Majid, Abdul, and Chaerul Rochman. Pendekatan Ilmiah Dalam Implementasi Kurikulum 2013. Bandung: Remaja Rosdakarya, 2014.

MOEC. Modul Penyusunan Higher Order Thinking Skill (HOTS). Jakarta, Indonesia: Ministry of Education and Culture (MOEC), 2017.

Moleong, Lexy J. Metodologi Penelitian Kualitatif. Bandung: Remaja Rosdakarya, 2017.

Mulyaningsih, Indrya, and Itaristanti Itaristanti. "Pembelajaran Bermuatan HOTS (Higher Order Thinking Skill) Di Jurusan Tadris Bahasa Indonesia." Indonesian Language Education and Literature 4, no. 1 (December 25, 2018): 113-28. https://doi.org/10.24235/ileal.v4i1.2970.

Noprinda, Chintia Tri, and Sofyan M. Soleh. "Pengembangan Lembar Kerja Peserta Didik (LKPD) Berbasis Higher Order Thinking Skill (HOTS)." Indonesian Journal of Science and Mathematics Education 2, no. 2 (July 31, 2019): 168-76. https://doi.org/10.24042/ijsme.v2i2.4342.

Pratiwi, Umi, and Eka Farida Fasha. "Pengembangan Instrumen Penilaian HOTS Berbasis Kurikulum 2013 Terhadap Sikap Disiplin." Jurnal Penelitian dan Pembelajaran IPA 1, no. 1 (November 12, 2015): 123-42. https://doi.org/10.30870/jppi.v1i1.330.

Priyatni, Endah Tri. Desain Pembelajaran Bahasa Indonesia Dalam Kurikulum 2013. Jakarta: Bumi Aksara, 2017.

Puspaningtyas, Nur Astuti. "Peningkatan Higher Order Thinking Skills (HOTS) Melalui Strategi Pembelajaran Peningkatan Kemampuan Berpikir (SPPKB) Pada 
Pembelajaran Ekonomi Kelas X SMK Muhammadiyah 1 Wates." Universitas Negeri https://eprints.uny.ac.id/59666/1/Skripsi_Nur\%20Astuti\%20Puspaningtyas_148 04244003.pdf.

Sani, Ridwan Abdulllah. Pembelajaran Berbasis HOTS (Higher Order Thinking Skills). Tangerang: Tira Smart, 2019.

Seman, Shamilati Che, Wan Mazwati Wan Yusoff, and Rahimah Embong. "Teachers Challenges in Teaching and Learning for Higher Order Thinking Skills (HOTS) in Primary School." International Journal of Asian Social Science 7, no. 7 (2017): 534-45, https://econpapers.repec.org/article/asiijoass/2017_3ap_3a534-545.htm.

Sufanti, Main. "Pembelajaran Bahasa Indonesia Berbasis Teks: Belajar Dari Ohio Amerika Serikat.” In Seminar Nasional: Teks Sebagai Media Pembelajaran Bahasa Indonesia Dalam Menyonsong Kurikulum, 36-65. Surakarta: Universitas Muhammadiyah Surakarta, 2013, https://publikasiilmiah.ums.ac.id/bitstream/handle/11617/3363/2_Pembelajaran \%20Bahasa\%20Indonesia\%20Berbasis\%20Teks\%20Belajar\%20Dari\%20Ohio $\% 20$ Amerika\%20Serikat.pdf?sequence $=1$.

Usmaedi, Usmaedi. "Menggagas Pembelajaran HOTS Pada Anak Usia Sekolah Dasar." Jurnal Pendidikan Sekolah Dasar 3, no. 1 (2017): 82, https://jurnal.untirta.ac.id/index.php/jpsd/article/view/1040.

Winarno, Winarno, Widha Sunarno, and Sarwanto Sarwanto. "Pengembangan Modul IPA Terpadu Berbasis High Order Thinking Skill (HOTS) Pada Tema Energi." INKUIRI: Jurnal Pendidikan IPA 4, no. 1 (2015): 82-91. https://doi.org/10.20961/inkuiri.v4i1.9562.

Yamin, Martinis. Paradigma Baru Pembelajaran. Jakarta: Referensi, 2013. 